\title{
Screening Arrayed Libraries with DNA and Protein Baits to Identify Interacting Proteins
}

\author{
Rocio Sánchez-Montesino and Luis Oñate-Sánchez
}

\begin{abstract}
Molecular interactions are an integral part of the regulatory mechanisms controlling gene expression. The yeast one- and two-hybrid systems $(\mathrm{Y} 1 \mathrm{H} / \mathrm{Y} 2 \mathrm{H})$ have been widely used by many laboratories to detect DNA-protein $(\mathrm{Y} 1 \mathrm{H})$ and protein-protein interactions $(\mathrm{Y} 2 \mathrm{H})$. The development of efficient cloning systems have promoted the generation of large open reading frame (ORF) clone collections (libraries) for several organisms. Functional analyses of such large collections require the establishment of adequate protocols. Here, we describe a simple straightforward procedure for high-throughput screenings of arrayed libraries with DNA or protein baits that can be carried out by one person with minimal labor and not requiring robotics. The protocol can also be scaled up or down and is compatible with several library formats. Procedures to make yeast stocks for long-term storage (tube and microplate formats) are also provided.
\end{abstract}

Key words Arrayed libraries, DNA-protein interaction, High-throughput, One-hybrid system, Open reading frame, Protein-protein interaction, Transcription factors, Two-hybrid system, Yeast

\section{Introduction}

The regulation of gene expression is paramount for proper development in any living organism and interactions between nucleic acids and proteins are an integral part of the underlying regulatory mechanisms. Transcriptional regulation is a crucial step in the cascade of events determining the final levels of a functional gene product and is mediated by short DNA sequences (cis-elements) located in gene promoters that are bound by transcription factor (TF) proteins. Specific combinations between TFs and promoter DNA sequences will render a specific transcriptional output. To reveal the complexity of this regulation as well as to study other interactomes not directly involved in the regulation of gene expression, the yeast two-hybrid ( $\mathrm{Y} 2 \mathrm{H})$ and one-hybrid ( $\mathrm{Y} 1 \mathrm{H})$ systems (Fig. 1) have been successfully and extensively used for detecting protein-protein and DNA-protein interactions, respectively. Compared to other approaches, these yeast systems require 


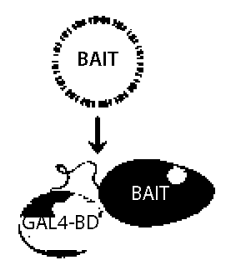

a

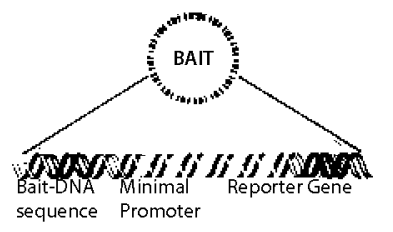

a
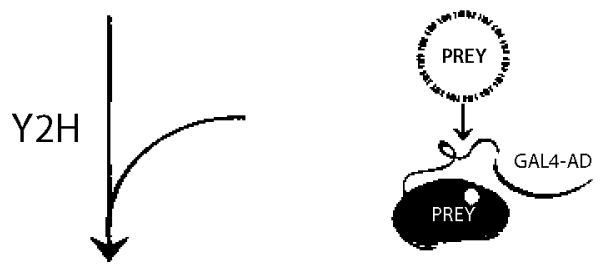

a

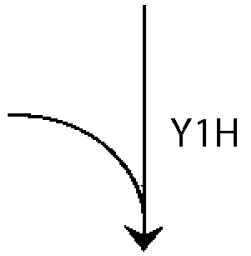

da
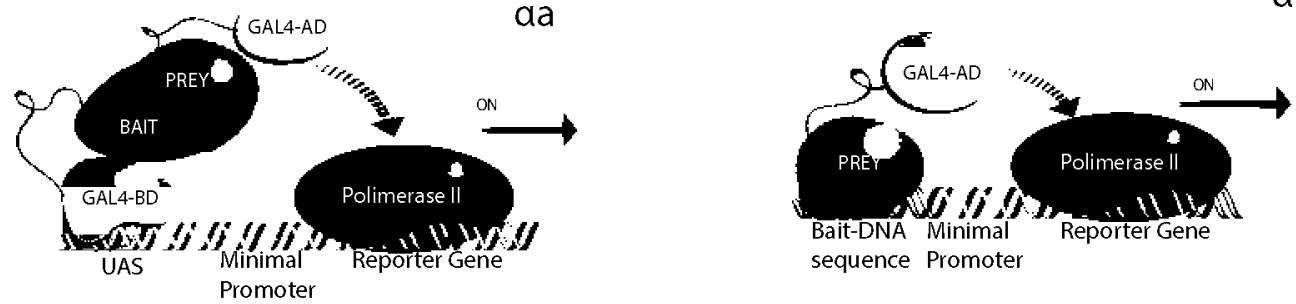

Fig. 1 Overview of the yeast one- $(\mathrm{Y} 1 \mathrm{H})$ and two-hybrid $(\mathrm{Y} 2 \mathrm{H})$ systems using mating. In the $\mathrm{Y} 2 \mathrm{H}$ system (left), a coding sequence for a protein of interest (Bait) is cloned in frame with the GAL4 DNA-binding domain (GAL4-BD) to produce a hybrid protein. Then, the coding sequence of another protein of interest (Prey) is cloned in frame with the GAL4 activation domain (GAL4-AD) to produce a hybrid protein (Prey). Both constructs are introduced into sexually compatible haploid yeast strains ( $\alpha$ and a) and diploid cells are obtained by mating ( $\alpha$ a). These cells carry a reporter gene under the control of a GAL4 binding DNA sequence (upstream activating sequence; UAS) that will be bound by the GAL4-BD-Bait. Transcription of the reporter gene will be enhanced if Bait and Prey proteins interact. The proteins of interest may be known (i.e., arrayed ORF libraries or in one-toone interactions) or unknown (i.e., cDNA libraries). In the $\mathrm{Y} 1 \mathrm{H}$ system (right), the bait construct is obtained by cloning a DNA sequence of interest (Bait-DNA sequence) upstream of a reporter gene carrying a minimal promoter. Both Bait-DNA and Prey (GAL4-AD-Prey) constructs are introduced in the same yeast cells where transcription of the reporter gene will be activated only if the prey binds the bait DNA

little specific optimization and provide an appropriate environment for interactions that depend on posttranscriptional modifications. Their basic principle relies on the modular structure of many TFs, with a DNA-binding domain (DBD) and a transactivation domain (AD) that can be physically separated while retaining their functions $[1,2]$. In a classic $\mathrm{Y} 2 \mathrm{H}$ system ([3]; Fig. 1), the coding sequence (CDS) for a protein of interest (bait) is fused to the CDS for the DBD of the yeast GAL4 TF (GAL4-BD), while the CDS for a second protein of interest (prey) is fused to the CDS for the AD of the GAL4 TF (GAL4-AD). The translation of the resulting CDSs will produce hybrid proteins (GAL4-BD-bait and GALA-AD-prey). If the bait and prey proteins interact when 
expressed in the same yeast cells, the GAL4-BD and GAL4-AD will be brought into close proximity enabling reconstitution of a fully functional GAL4 TF. By using appropriate yeast strains, the reconstituted GAL4 TF will bind (by its BD domain) GAL4-

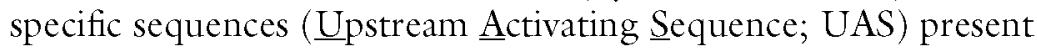
in the promoters of reporter genes and will activate (by its $\mathrm{AD}$ domain) their expression (Fig. 1). The YlH system is conceptually similar to the yeast two-hybrid system [4-8]. In this case, the bait construct contains a reporter gene under the control of a DNA sequence of interest. The interaction of a prey protein (GAL4-AD-prey) with the DNA bait will activate the expression of the reporter gene (Fig. 1). In both systems, the positive effect of the GAL4-AD on the transcription of the reporter gene is dominant over the transcriptional properties that may have proteins of interest fused to this domain (i.e., a repressor domain, absence of regulatory domains, etc.), which enable the identification of a wider range of interactions $[1,2]$.

Since the original description of the $\mathrm{Y} 1 \mathrm{H}$ and $\mathrm{Y} 2 \mathrm{H}$ systems, several variations and refinements have allowed to enlarge the range of interactors that can be tested as well as to increase the throughput [9-16]. Apart from these considerations, the type of DNA sequence (size and multimerization) selected as bait for $\mathrm{YlH}$ can be critical in determining the outcome of the experiment (see Note 1; Fig. 2). Also, in $\mathrm{Y} 2 \mathrm{H}$ assays, protein baits containing strong transactivation domains may impede detection of further enhancements in activation levels of the reporter gene upon interaction with a prey ( see Note 2 ).

In plants, collections of open reading frames (ORF), several of them dedicated to TFs, have been generated and used in $\mathrm{YlH}$ and $\mathrm{Y} 2 \mathrm{H}$ screenings [17-27]. Here we describe a simple method for high-throughput screenings of arrayed ORF libraries with DNA $(\mathrm{Y} 1 \mathrm{H})$ or protein $(\mathrm{Y} 2 \mathrm{H})$ baits not requiring robotics (Fig. 3). Briefly, mating of sexually compatible strains in liquid media is used to combine bait and prey constructs in the same yeast cells (diploids). After mating, liquid cultures are scored for diploids according to their ability to grow on selective solid media (positive interactions). It only requires approximately $10 \mathrm{~h}$ of labor spread over 5 days. Additionally, this methodology can be scaled up or down and can be easily adapted to use with other library formats or/and yeast strains.

\section{Materials}

\subsection{Media and Reagents}

Prepare all media using deionized water. Add adenine hemisulfate $(30 \mathrm{mg} / \mathrm{L} ;$ see Note 3 ) to minimal and YPAD media. If preparing solid media, add $20 \mathrm{~g} / \mathrm{L}$ agar. Unless otherwise indicated, sterilise 
a
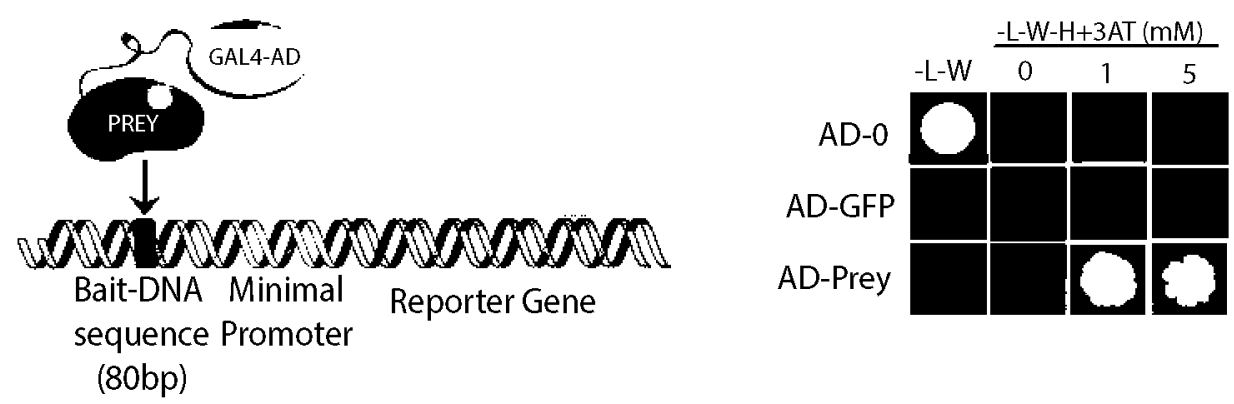

b
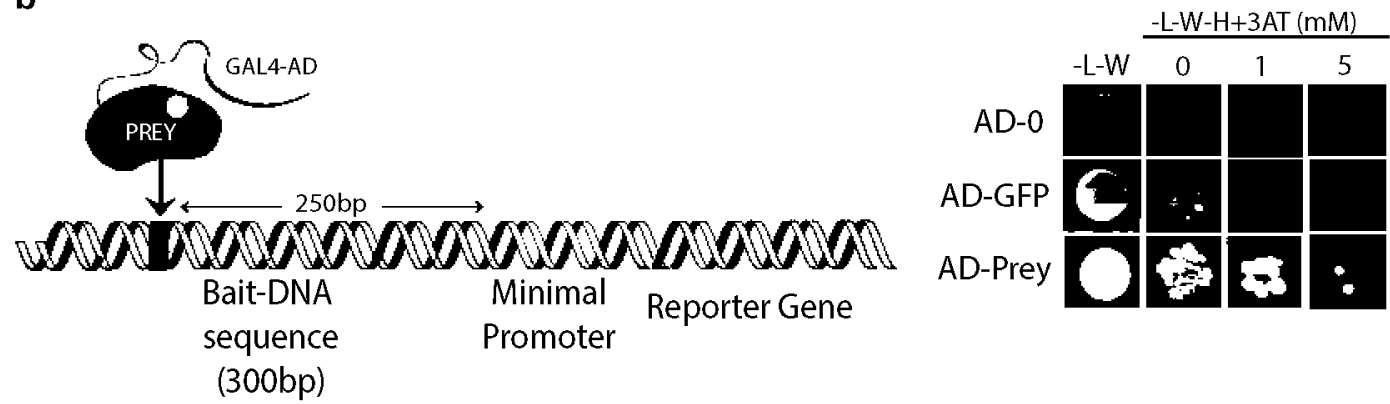

Fig. 2 Effect of the distance between the bait DNA and the reporter gene in the sensitivity of the $\mathrm{Y} 1 \mathrm{H}$ system. (a) A 80 bp bait DNA sequence bound by a prey protein that activates HIS3 reporter expression. Dense yeast growth is observed in the presence of all 3-AT concentrations tested. (b) Yeast growth (reporter activation) drops drastically when the same Bait DNA is shifted 250 bp further upstream of the reporter gene (R. SánchezMontesino and L. Oñate-Sánchez, unpublished results)

by autoclaving media for 20 min at $120^{\circ} \mathrm{C}$. We store media at $4{ }^{\circ} \mathrm{C}$ in darkness or subdued light.

1. Minimal media (see Note 4): Dissolve $26.7 \mathrm{~g} / \mathrm{L}$ of dropout base medium (DOB contains $1.7 \mathrm{~g}$ yeast nitrogen base, $5 \mathrm{~g}$ ammonium sulfate, $20 \mathrm{~g}$ glucose) and the appropriate amount of a complete supplement mixture (CSM) of amino acids lacking the one/s used for auxotrophic selection: CSM-leucine (CSM-L; $0.69 \mathrm{~g} / \mathrm{L})$; CSM-tryptophan (CSM-W; $0.74 \mathrm{~g} / \mathrm{L})$; CSM-leucine-tryptophan (CSM-L-W; 0.64 g/L); CSMleucine-tryptophan-histidine (CSM-L-W-H; $0.62 \mathrm{~g} / \mathrm{L})$. The $\mathrm{pH}$ does not need to be adjusted but it should be in the 5-5.5 range. Autoclave for only $10 \mathrm{~min}$ at $120^{\circ} \mathrm{C}$ ( see Note 5).

2. YPAD: Dissolve $20 \mathrm{~g} / \mathrm{L}$ peptone, $10 \mathrm{~g} / \mathrm{L}$ yeast extract, adjust $\mathrm{pH}$ to 5.8 with $\mathrm{HCl}$, top up to $950 \mathrm{ml}$ with water and autoclave. When the media cools down to $50-60^{\circ} \mathrm{C}$, add $50 \mathrm{ml}$ of a $40 \% \mathrm{w} / \mathrm{v}$ glucose solution ( $2 \%$ final concentration).

3. Glucose 40\%: Dissolve $40 \mathrm{~g}$ glucose in $100 \mathrm{ml}$ water and autoclave. 

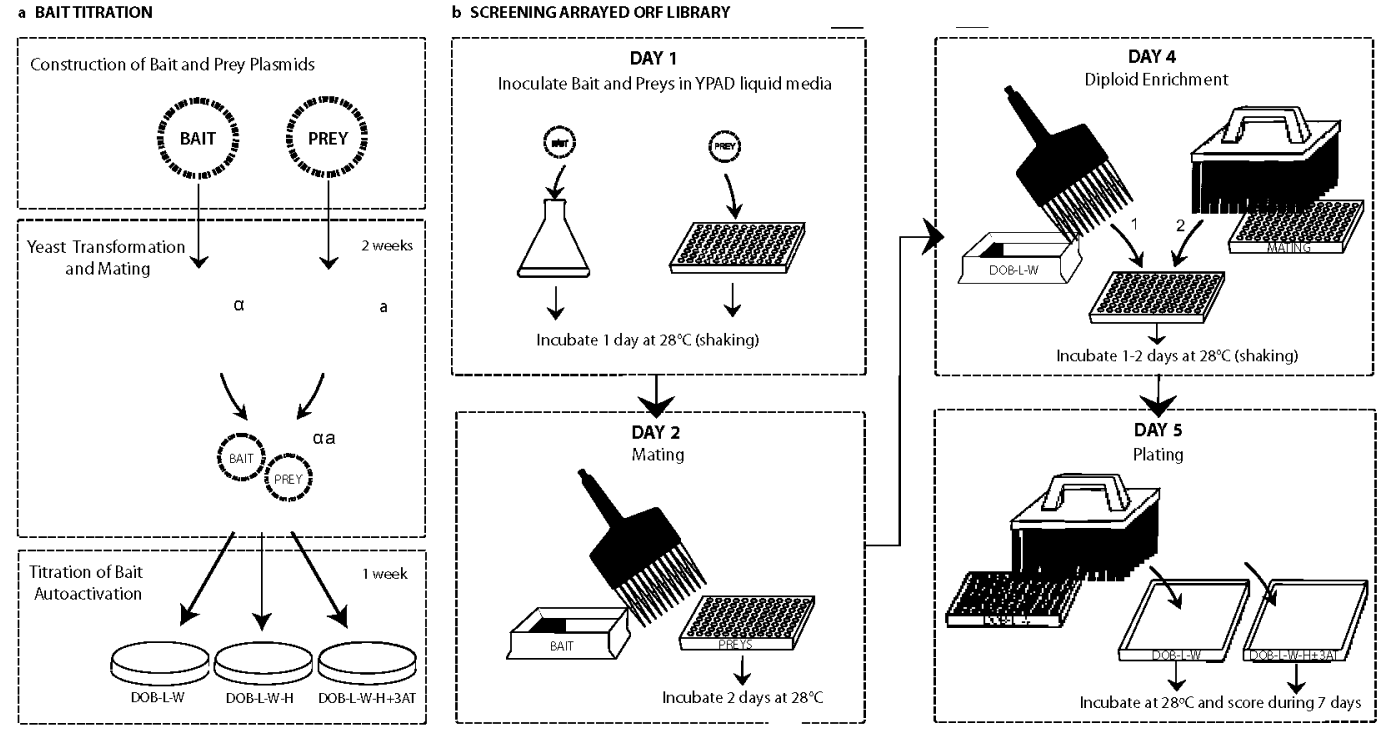

Fig. 3 Outline for bait titration and screening methods. (a) After cloning bait (DNA or protein ORFs) and preys (control and proteins of interest ORFs) into appropriate plasmids, they are introduced into sexually compatible yeast strains (yeast transformation), which are mated to obtain diploids that are tested for activation of the reporter gene. Conditions that block reporter activation in yeast cells containing bait and control preys should be chosen for the screening (see Subheading 3.3). The bait titration procedure can also be used for testing one or few selected interactions. (b) Bait and ORF library clones growing on plates with their corresponding auxotrophic media (DOB-L for baits and DOB-W for preys), are used to inoculate Erlenmeyer flasks and 96-well microtiter plates, respectively, containing YPAD (Day 1). After $24 \mathrm{~h}$ incubation, bait and preys are then mixed and incubated for $48 \mathrm{~h}$ to allow mating (Day 2). Mated cells are used to inoculate 96 -well microtiter plates with DOB-L-W for diploid enrichment (Day 4). After incubation for 24-48 h, diploid cells are replica-spotted onto diploid (DOB-L-W) and screening (DOB-L-W-H $\pm 3-A T$ ) plates (Day 5). The 3-AT concentration required to block reporter activation in the absence of a true interaction should have been previously determined as indicated in (a). Positive interactions (growth on screening plates) should appear between 1 and 7 days of incubation (see Subheading 3.4). Typically, the total time from inoculation of bait and preys until final screening results are obtained is about 12 days 
4. 3-Amino-1,2,4-triazole (3-AT; see Note 6): Dissolve the appropriate amount of 3 -AT in water to obtain a $2 \mathrm{M}$ solution (i.e., $4.2 \mathrm{~g}$ in $25 \mathrm{ml}$ water). Sterilize by filtration $(0.45$ or $0.22 \mu \mathrm{m}$ pore size) and store this stock solution in darkness at $-20{ }^{\circ} \mathrm{C}$. When required, add the appropriate amount of the 3-AT stock solution to autoclaved minimal media (DOB-L$\mathrm{W}-\mathrm{H}$ ) once it has cooled down to $50-60^{\circ} \mathrm{C}$.

5. Yeast transformation solution (PATE): Prepare and autoclave stock solutions of $50 \% \mathrm{w} / \mathrm{v}$ polyethylene glycol 4000 (PEG; see Note 7), $1 \mathrm{M}$ lithium acetate (LiAc) and $10 \times$ Tris-EDTA $\mathrm{pH}: 8$ (10× TE: $100 \mathrm{mM}$ Tris, $10 \mathrm{mM}$ disodium EDTA, $\mathrm{pH} 8.0$ with $\mathrm{HCl}$ ). To prepare the PATE solution, mix the stock solutions to obtain $40 \% \mathrm{w} / \mathrm{v}$ PEG $4000,0.1 \mathrm{M} \mathrm{LiAc}$, and $1 \times \mathrm{TE}$.

6. Salmon sperm DNA (SsDNA; see Note 8): To prepare a $10 \mathrm{mg} / \mathrm{ml}$ stock salmon sperm DNA (carrier DNA) dissolve $10 \mathrm{mg}$ of type III salmon sperm DNA (sodium salt) in $1 \mathrm{ml}$ of water (it is recommendable to leave the mix dissolving overnight). Pass the solution vigorously through a gauge 21 needle (2l-G) 20 times to shear DNA. Sonicate in an icewater bath until the viscosity of the solution decreases $(\sim 3-4 \mathrm{~min})$, incubate at $95{ }^{\circ} \mathrm{C}$ for $10 \mathrm{~min}$ and cool it down quickly by transferring it to ice. Store at $-20{ }^{\circ} \mathrm{C}$ in small aliquots (i.e., $100 \mu \mathrm{l}$ ).

7. Glycerol 50\%: Mix equal volumes of glycerol and water and autoclave.

8. Absolute ethanol (see Note 9).

9. Yeast plasmid miniprep kit or equivalent protocol to isolate plasmid DNA.

10. Oligonucleotides: p'TUY1H-F (5'-CACGAGGCCCTTTC GTCTTC-3'; forward primer annealing before the XmaI/SmaI site of the pTUYlH), pTUYlH-R (5'-TTCTTCGAAGAA ATCACATTAC- $3^{\prime}$; reverse primer annealing after the XbaI site of the pTUYlH), GAL4AD-F (5'-TATAACGCGTTT GGAATCACT-3'; forward primer annealing near the C-terminal region of the GAL4-AD in the pDEST22 plasmid), pDEST-R (5'-AGCCGACAACCTTGATTGGAGAC-3'; reverse primer annealing downstream of the gateway region in the pDEST22 and pDEST32 plasmids) and GALABD-F (5'-TCATCGGAAGAGAGTAGTAA-3'; forward primer annealing near the C-terminal region of the GAL4-AD in the pDEST32 plasmid).

11. Yeast strains: Table 1 .

12. Plasmids: Table 2.

13. ORF library or custom-made clone collection (see Note 10). 


\begin{tabular}{|c|c|c|c|c|}
\hline $\begin{array}{l}\text { Strain } \\
\text { (mating } \\
\text { type) }\end{array}$ & Genotype & Reporters & $\begin{array}{l}\text { Auxotrophy/ } \\
\text { Transformation } \\
\text { markers }\end{array}$ & Reference \\
\hline $\begin{array}{l}\text { YM4271 } \\
\text { (a) }\end{array}$ & $\begin{array}{l}\text { MATa, ura3-52, his } 3-200, \text { ade2-101, } \\
\text { ade5, lys2-801, leu2-3,112, trp 1-901, } \\
\text { tyrl-501, gal4 } 4 \text {, gal } 80 \Delta \text {, ade5::hisG }\end{array}$ & & $\begin{array}{l}\operatorname{trp} 1, \text { leu2, his } 3 \\
\quad \text { ura3, lys } 2\end{array}$ & [28] \\
\hline Y187 $(\alpha)$ & 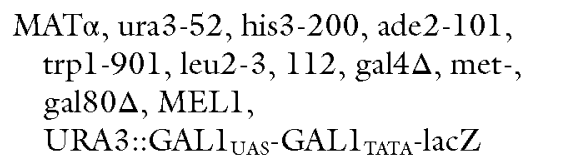 & $\begin{array}{r}\text { MEL1, } \\
\text { LacZ }\end{array}$ & $\begin{array}{l}\operatorname{trp} 1, \text { leu } 2, \text { his } 3 \text {, } \\
\text { ade } 2, \text { met } 2\end{array}$ & [29] \\
\hline pJ694 ( $\alpha)$ & $\begin{array}{l}\text { MAT } \alpha, \operatorname{trpl}-901 \text { leu2-3, } 112, \text { ura3-52, } \\
\text { his3-200, gal4 } \Delta, \text { gal } 80 \Delta, \text { LYS2::GAL1- } \\
\text { HIS3, GAL2-ADE2, met2::GAL7-lacZ }\end{array}$ & $\begin{array}{l}\text { His3, } \\
\text { Ade2, } \\
\text { LacZ }\end{array}$ & $\begin{array}{l}\operatorname{trp} 1, \text { leu } 2, \text { ura } 3 \text {, } \\
\text { met } 2\end{array}$ & [30] \\
\hline
\end{tabular}

None of these strains grow on -L, -W, -H, -M, -Ade, -Ura, except for Y187 (positive growth on -Ura) and YM4271 (positive growth on -Met)

\section{Table 2}

\section{Plasmids used for $\mathrm{Y} 1 \mathrm{H}$ and $\mathrm{Y} 2 \mathrm{H}$ assays}

\begin{tabular}{lllll}
\hline Plasmid & Cloning & $\begin{array}{l}\text { Bacterial } \\
\text { selection }\end{array}$ & Yeast selection & Reference \\
\hline pTUY1H (DNA bait for Y1H) & $\begin{array}{c}\text { XmaI- } \\
\text { XbaI }\end{array}$ & Ampicillin & Leucine (L) & {$[22]$} \\
pDEST32 (protein bait for Y2H) & Gateway & Gentamicin & Leucine (L) & Invitrogen \\
$\begin{array}{l}\text { pDEST22 (protein prey for Y1H and } \\
\text { Y2H) }\end{array}$ & Gateway & Ampicillin & Tryptophan (W) & Invitrogen \\
\hline
\end{tabular}

2.2 Disposables and Small Equipment
Reagent reservoirs, $120 \mathrm{~mm}$ square petri plastic plates, 96-well plates (standard sterile clear plates with lid and flat bottom; $300 \mu \mathrm{l}$ max. volume/well), surgical tape, Parafilm tape, multichannel pipettes (electronic or manual 12- or 8-channel pipettes to dispense volumes in the range of 100-250 $\mu$ ), 96-well replicator (see Note 11 and Fig. 4), Erlenmeyer flasks ( $500 \mathrm{ml}$ or $1 \mathrm{~L}$ ), microtiter plate shaker (see Note 12), standard shaker, laminar flow cabinet.

Optional: $90 \mathrm{~mm}$ diameter petri plates, cryogenic vials.

\section{Methods}

Manipulation of yeasts should always be done under sterile conditions. 


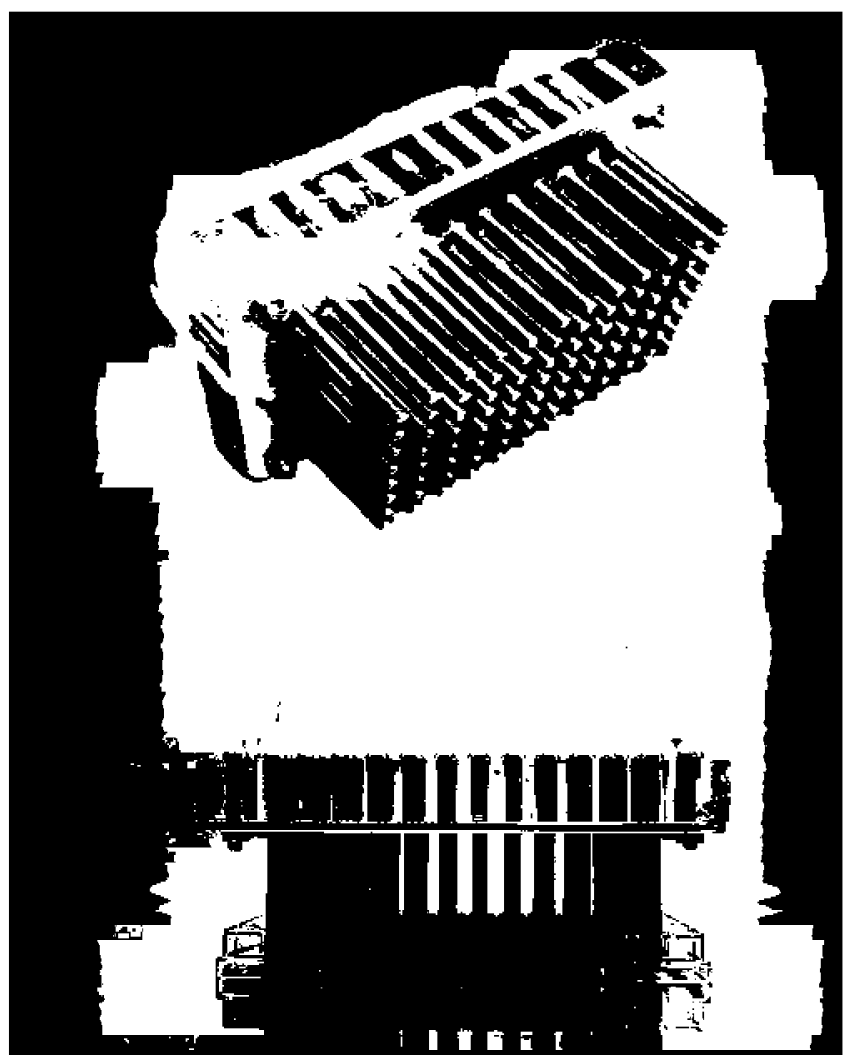

Fig. 4 Close-up picture of the custom-made replicator

\subsection{Preparation of DNA or Protein} Baits for Screenings
1. Bait for YlH: Prepare a construct with your bait DNA sequence in the pTUYlH plasmid (Table 2 ; see Notes $\mathbf{1}$ and $13 ;[22]$ ). Introduce this construct (DNA bait) into $S$. cerevisiae Y187 ( $\alpha$ mating type; Table $1 ;$ [29]) and select transformants in DOB-L plates (see Subheading 3.2).

2. Preys for $\mathrm{Y} 1 \mathrm{H}$ and $\mathrm{Y} 2 \mathrm{H}$ : As a prey negative control and to titrate your baits, prepare another construct with the CDS of a protein unlikely to interact with your bait (i.e., the GFP coding sequence) in the pDEST22 plasmid (Invitrogen; Table 2; see Notes 2 and 14). Separately, introduce this construct (AD-GFP) and the empty pDEST22 plasmid (AD-empty) into S. cerevisiae YM4271 ("a" mating type; Table $1 ;$ [28]) and select transformants in DOB-W plates (see Subheading 3.2). If available, generate a prey strain with the pDEST22 plasmid containing an ORF known to interact with your bait, as a positive control.

3. Bait for $\mathrm{Y} 2 \mathrm{H}$ : Prepare a construct with your bait protein CDS in the pDEST32 gateway plasmid (Invitrogen; Table 2; see Notes 2 and 14). Introduce this construct (bait) into S. cerevisiae pJ694 ( $\alpha$ mating type; Table $1 ;[30])$ and select transformants in DOB-L plates (see Subheading 3.2). 


\subsection{Yeast \\ Transformation \\ (Modified from [31])}

4. For sequencing or PCR amplification of bait and prey constructs, the following oligonucleotides can be used: pTUYlH-F (forward) or/and pTUYlH-R (reverse) for the pTUYlH plasmid, GAL4BD-F (forward) or/and pDEST-R (reverse) for the pDEST32 plasmid, and GALAAD-F (forward) or / and pDEST-R (reverse) for the pDEST22 plasmid.

1. Streak a YPAD plate with the appropriate yeast strain from a frozen stock and incubate for $2-3$ days at $28^{\circ} \mathrm{C}$.

2. Inoculate $5 \mathrm{ml}$ of liquid $\mathrm{YPAD}$ with a fresh colony and grow for $24 \mathrm{~h}$ at $28^{\circ} \mathrm{C}$ with shaking.

3 . Fill an eppendorf tube with the yeast culture (usually having $\mathrm{OD}_{600} \sim 1.5-2$ ) and centrifuge at $3500 \mathrm{rcf}$ for $2 \mathrm{~min}$. Discard supernatant and repeat this step until a pellet of $\sim 50 \mu$ l of yeast cells is obtained $(\sim 3 \mathrm{ml}$ of culture). After the last centrifugation, pour off supernatant by inverting the tube and remove excess liquid by gently stroking the eppendorf twice in an inverted position. Resuspend yeast cells in the remaining liquid $(\sim 100 \mu$ l total volume) by flicking the bottom of the eppendorf tube with the fingertips. Add carrier DNA (usually 10-20 $\mu$ of a $10 \mathrm{mg} / \mathrm{ml}$ salmon sperm DNA stock; see Note 8) and mix by flicking; add $0.5-1 \mu \mathrm{g}$ of plasmid DNA $(\leq 20 \mu \mathrm{l})$ and mix by flicking; add $500 \mu \mathrm{l}$ PATE solution and mix by flicking. Incubate the tube overnight ( see Note 15) at room temperature (i.e., inside a drawer).

4. Centrifuge yeast cells at 3500 ref for $2 \mathrm{~min}$, remove completely the supernatant with a pipette, and resuspend the cells in $1 \mathrm{ml}$ sterile water. Repeat this step twice and resuspend cells in $150 \mu \mathrm{l}$ sterile water after the second repetition (pipetting up and down can be used to help with cell resuspension if required).

5. Plate yeast cells onto appropriate auxotrophic minimal media for positive selection of cells carrying the introduced plasmid. Colonies will appear after $2-3$ days incubation at $28^{\circ} \mathrm{C}$.

1. Pick several colonies (3-5) from transformation plates and streak them onto new plates of the appropriate minimal media. After $48 \mathrm{~h}$ incubation at $28^{\circ} \mathrm{C}$, use fresh colonies to inoculate $10 \mathrm{ml}$ tubes containing $1-2 \mathrm{ml}$ YPAD each (tube 1 : bait strain; tube 2: AD-GFP prey strain; tube 3: AD-empty prey strain). Grow at $28^{\circ} \mathrm{C}$ with shaking for $24 \mathrm{~h}$ (overnight is usually enough).

2. Mating: Mix $200 \mu \mathrm{l}$ of the bait culture with $200 \mu \mathrm{l}$ of the prey cultures (tube $1+$ tube 2 and tube $1+$ tube 3 ) in sterile eppendorf tubes and incubate $1-2$ days at $28{ }^{\circ} \mathrm{C}$ without shaking (24 h is usually enough to obtain diploids). 
3. Enrichment for diploid cells: Use $200 \mu \mathrm{l}$ of the mated cultures to inoculate $2 \mathrm{ml}$ of liquid DOB-L-W media in $10 \mathrm{ml}$ tubes. Grow at $28^{\circ} \mathrm{C}$ with shaking for $48 \mathrm{~h}$ ( $24 \mathrm{~h}$ is usually enough).

4. Plating diploid cells (see Note 17): Prepare two serial dilutions from the diploid enriched cultures $\left(10^{-1}\right.$ and $\left.10^{-2}\right)$. Plate $5 \mu \mathrm{l}$ drops of each dilution and undiluted cultures onto the following agar media: DOB-L-W (for quantification of diploid cells), DOB-L-W-H and DOB-L-W-H + 3-AT (a range of concentrations for quantification of bait activation of the reporter gene). Incubate plates at $28^{\circ} \mathrm{C}$ and score yeast growth over the following 7 days after plating.

3.4 Screening Yeast Arrayed Libraries (See Notes 11 and 18 and Fig. 3b)
When modifications in the method are required to screen two baits (two screenings) simultaneously, a reference to Table 3 has been inserted in the text where they are listed in chronological order. Table 4 summarizes media and disposables required for one or two screenings.

1. Day 0: Using a 96-well replicator (Fig. 4), make a replica of the library $(15 \times 96$-well plates $)$ on DOB-W square agar plates (15 square plates). Also, streak one DOB-L plate (Table 3) with the bait strain. Incubate all plates at $28{ }^{\circ} \mathrm{C}$ during 48-72 h.

2. Day 1: Dispense YPAD in a sterile reagent reservoir and, using a multichannel pipette, aliquot $125 \mu \mathrm{l}$ (Table 3 ) of YPAD into each well of 96 -well microtiter plates ( 15 microtiter plates). By using a replicator, inoculate 96 -well microtiter plates with the library prey strains grown on DOB-W square agar plates. Cover microtiter plates with the lid and seal them with surgical tape. Shake (250 rpm; see Note 12) and incubate at $28^{\circ} \mathrm{C}$ for $24 \mathrm{~h}$. In parallel, inoculate one (Table 3) 0.5-1 L Erlenmeyer containing $200 \mathrm{ml}$ of YPAD with a clump of bait cells (5-10 colonies) from the DOB-L plate and incubate for 24 h at $28^{\circ} \mathrm{C}$ with shaking (200 rpm).

3. Day 2 (mating):

Before starting this step and only if two baits are screened, transfer $100 \mu \mathrm{l}$ of culture from each well of microtiter plates from day 1 to a second set of $15 \times 96$-well microtiter plates using a multichannel pipette (pipette up and down two or three times to resuspend any settled cells at the bottom of the wells before transferring any liquid to a new plate).

Dispense the YPAD culture for the bait into a sterile reagent reservoir and, using a multichannel pipette, add $100 \mu l$ to each well of the $15 \times 96$-well microtiter plates from day 1 (Table 3 ). Incubate $2-3$ days at $28^{\circ} \mathrm{C}$ without shaking.

4. Day 4 (diploid enrichment): Dispense DOB-L-W into a sterile reagent reservoir and, using a multichannel pipette, add $200 \mu \mathrm{l}$ to each well of new $15 \times 96$-well microtiter plates (Table 3). Resuspend settled mated cells in the $15 \times 96$-well microtiter 
1. Replicate library in DOB-W square agar plates

2. Streak bait in a DOB-L agar plate

3. Incubate 1 day at $28^{\circ} \mathrm{C}$

$$
\text { Day } 1
$$

1. Add $125 \mu \mathrm{l}$ YPAD in $15 \times 96$-well microtiter plates

2. Inoculate library from DOB-W agar plates

3. Inoculate bait in a $0.5-1 \mathrm{~L}$ Erlenmeyer containing $200 \mathrm{ml}$ YPAD

4. Incubate 1 day at $28^{\circ} \mathrm{C}$ with shaking

Day 2

1. Dispense the bait culture into a reservoir

2. Add $100 \mu \mathrm{l} /$ well of the $15 \times 96$-well microtiter plates from day 1

3. Incubate 2 days at $28^{\circ} \mathrm{C}$ without shaking

Day 4

1. Dispense DOB-L-W in a reservoir and add $200 \mu \mathrm{l} /$ well to a new set of $15 \times 96$-well microtiter plates

2. Inoculate these plates with the mated cells in the $15 \times 96$-well microtiter plates from day 2 by using the replicator

3. Incubate 2 days at $28^{\circ} \mathrm{C}$ with shaking

\section{Day 5}

1. Resuspend the set of $15 \times 96$-well microtiter plates and plate into DOB-L-W and DOB-L-W-H $\pm 3 \mathrm{AT}$ agar plates by using the replicator

2. Incubate at $28^{\circ} \mathrm{C}$ and check plates for 7 days
1. Replicate library in DOB-W square agar plates

2. Streak baits in DOB-L agar plates

3. Incubate 1 day at $28^{\circ} \mathrm{C}$

1. Add $250 \mu 1$ YPAD in $15 \times 96$-well microtiter plates

2. Inoculate library from DOB-W agar plates

3. Inoculate each bait in a $0.5-1 \mathrm{~L}$ Erlenmeyer containing $200 \mathrm{ml}$ YPAD

4. Incubate 1 day at $28^{\circ} \mathrm{C}$ with shaking

1. Transfer $100 \mu 1$ of culture from microtiter plates from day 1 to a second set of $15 \times 96$-well microtiter plates

2. Dispense each bait culture into a reservoir

3. Add $100 \mu \mathrm{l} /$ well of each bait in different sets of $15 \times 96$-well microtiter plates

4. Incubate 2 days at $28^{\circ} \mathrm{C}$ without shaking

1. Dispense DOB-L-W in a reservoir and add $200 \mu \mathrm{l} /$ well to two new sets of $15 \times 96$-well microtiter plates

2. Inoculate these plates with the mated cells in the two sets of $15 \times 96$-well microtiter plates from day 2 by using the replicator

3. Incubate 2 days at $28{ }^{\circ} \mathrm{C}$ with shaking

1. Resuspend both sets of $15 \times 96$-well microtiter plates and inoculate in DOB-L-W and DOB-L-W-H $\pm 3 \mathrm{AT}$ agar plates by using the replicator

2. Incubate at $28^{\circ} \mathrm{C}$ and check plates for 7 days

${ }^{a}$ Changes in the procedure when doing two screenings simultaneously have been highlighted in bold 


\section{Table 4}

\section{Materials for one or two screenings}

\begin{tabular}{|c|c|}
\hline One Screening & Two Screenings ${ }^{a}$ \\
\hline \multicolumn{2}{|c|}{ Day 0} \\
\hline $15 \times$ DOB-W square agar plates & $15 \times \mathrm{DOB}-W$ square agar plates \\
\hline $1 \times$ DOB-L agar plate & $2 \times$ DOB-L agar plates \\
\hline 1 replicator & 1 replicator \\
\hline \multicolumn{2}{|c|}{ Day 1} \\
\hline 1 multichannel pipette $\mathrm{p} 200 / \mathrm{p} 1000$ & 1 multichannel pipette $\mathrm{p} 200 / \mathrm{p} 1000$ \\
\hline 1 reservoir & 1 reservoir \\
\hline $15 \times 96$-well microtiter plates & $15 \times 96$-well microtiter plates \\
\hline 1 autoclaved $0.5-1 \mathrm{~L}$ Erlenmeyer & 2 autoclaved $0.5-1$ L Erlenmeyer \\
\hline 1 replicator & 1 replicator \\
\hline $400 \mathrm{ml}$ YPAD & $800 \mathrm{ml}$ YPAD \\
\hline \multicolumn{2}{|c|}{ Day 2} \\
\hline \multirow[t]{2}{*}{1 multichannel pipette $\mathrm{p} 200 / \mathrm{p} 1000$} & 1 multichannel pipette $\mathrm{p} 200 / \mathrm{p} 1000$ \\
\hline & $15 \times 96$-well microtiter plates \\
\hline \multirow[t]{2}{*}{1 reservoir } & 2 reservoirs \\
\hline & $15 \times 96$-pipette tip racks \\
\hline \multicolumn{2}{|c|}{ Day 4} \\
\hline 1 multichannel pipette $\mathrm{p} 200 / \mathrm{p} 1000$ & 1 multichannel pipette $\mathrm{p} 200 / \mathrm{p} 1000$ \\
\hline 1 reservoir & 1 reservoir \\
\hline $15 \times 96$-well microtiter plates & $30 \times 96$-well microtiter plates \\
\hline $300 \mathrm{ml}$ DOB-L-W & $600 \mathrm{ml} \mathrm{DOB}-\mathrm{L}-\mathrm{W}$ \\
\hline \multicolumn{2}{|c|}{ Day 5} \\
\hline 1 replicator & 1 replicator \\
\hline $15 \times$ DOB-L-W & $30 \times$ DOB-L-W \\
\hline $15 \times$ DOB-L-W-H $\pm 3 \mathrm{AT}$ & $30 \times \mathrm{DOB}-\mathrm{L}-\mathrm{W}-\mathrm{H} \pm 3 \mathrm{AT}$ \\
\hline
\end{tabular}

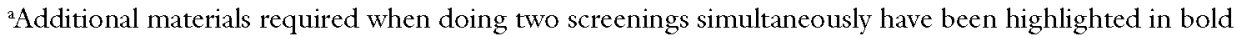

plates from day 2 , by hitting the bottom of the wells with the pins of the replicator, and use it to inoculate the new $15 \times 96$-well DOB-L-W microtiter plates (Table 3) previously prepared. Shake ( $2.8 \mathrm{rcf} ;$ see Note 12$)$ and incubate at $28^{\circ} \mathrm{C}$ for $24-48 \mathrm{~h}$ ( $72 \mathrm{~h}$ are also fine). 


\subsection{Confirming Positive Interactions and Quantifying Strength}

\subsection{Making Yeast Glycerol Stocks for Long-Term Storage}

5. Day 5: Resuspend any settled cells by hitting the bottom of the wells with the pins of the replicator and, for each 96-well DOB-L-W microtiter plate from day 4 , inoculate two square agar plates, one with DOB-L-W (diploid plates) and another with DOB-L-W-H \pm 3-AT (screening plates; the concentration of 3-AT required should have been previously determined in Subheading 3.3). Close square agar plates with their corresponding lids and seal them with Parafilm once the droplets left by the replicator dry out. Incubate the plates at $28^{\circ} \mathrm{C}$ and score yeast growth during 7 days (see Note 19).

1. Use diploid cells able to grow in screening plates to inoculate $5 \mathrm{ml} \mathrm{DOB}-\mathrm{W}$ and incubate for $48 \mathrm{~h}$ at $28^{\circ} \mathrm{C}$ with shaking (standard shaker).

2. These cultures can now be used to isolate the $\mathrm{AD}$-prey plasmid responsible for the interaction and the activation of the reporter gene ( see item 9 in Subheading 2.1).

3. Transform Escherichia coli with the isolated plasmid, reisolate the plasmid from the transformed bacteria and sequence the prey ORF with the oligonucleotides GALAAD-F and/or pDEST-R ( see item 10 in Subheading 2.1).

4. Reintroduce the isolated plasmid into the YM4271 yeast strain (see Subheading 3.2) and mate the resulting strain with the bait strain. Alternatively, the plasmid may be directly introduced into the bait strain ( $\mathrm{see}$ Note 20).

5 . The resulting yeast strains should be analyzed as described in the titration section (from step 3 of Subheading 3.3) in order to confirm the interactions and their strengths (a more comprehensive and narrow range of 3 -AT concentrations can now be used).

To avoid maintenance of yeast cells by repeatedly refreshing colonies in agar plates stored at $4^{\circ} \mathrm{C}$, permanent stocks can be prepared by following the steps described in this section.

Single Tube Format

1. Spread 100-200 $\mu$ l of a grown culture of the yeast strain onto an appropriate minimal media plate. Alternatively, you can streak a generous quantity of cells evenly over the plate. A lawn of cells should be seen after incubation for 48 h at $28^{\circ} \mathrm{C}$.

2. Collect grown cells (usually a quarter of a $90 \mathrm{~mm}$ diameter petri plate is enough) from the agar plate by rubbing them with a sterile loop or pipette tip. Resuspend the cells in a cryogenic vial containing $800 \mu \mathrm{l}$ sterile water (YPAD or the corresponding selection media is also fine) and add $1.2 \mathrm{ml} 50 \%$ glycerol ( $30 \%$ final concentration). Shake or/and vortex for homogeneous cell suspension. 
3. Store the vial directly at $-80^{\circ} \mathrm{C}$ for long-term storage (see Note 21). Frozen stocks can be refreshed on the appropriate auxotrophic media or YPAD.

\section{Microtiter Plate Format}

Add glycerol up to $30 \%$ final concentration to each well of a microtiter plate containing grown yeast strains (YPAD or minimal media). Mix well by pipetting up and down two or three times and seal the plates (use a sterile sticky seal resistant to storage conditions). Store at $-80^{\circ} \mathrm{C}$.

\section{Notes}

1. Try using promoter fragments not much longer than $100 \mathrm{bp}$. $S$. cerevisiae genome is more compact than those of multicellular eukaryotes and it is known that for regulated cissequences located over 300 bp upstream of a reporter gene, transcription initiates proximally to the UAS and competes with that derived from the reporter gene located downstream [32]. In our hands, the sensitivity of the assay is greatly reduced when the bound DNA sequence is in the context of a long promoter fragment (i.e., an $80 \mathrm{bp}$ sequence in a $300 \mathrm{bp}$ promoter fragment; Fig. 2). Also, using multimerized sequences tends to give higher backgrounds than using just one copy of the selected DNA sequence (L. Oñate-Sánchez, unpublished results).

2. An option is to use a truncated version of the bait protein with reduced activation levels, although the possibility that the deleted portion of the protein may be involved in interactions cannot be ruled out. Another alternative is to use a different system in which the activation of the reporter gene does not directly rely on the transcriptional properties of the interactors (i.e., $[33,34]$ ).

3. All yeast strains used here carry the ade2-101 mutation. If grown on normal media not supplemented with adenine (low in adenine), colonies will develop a pink or red color due to the accumulation of a pigment derivative of 5 -aminoimidazole ribotide in vacuoles $[35,36]$. Adding adenine hemisulfate $(30 \mathrm{mg} / \mathrm{L})$ to media also enhance yeast growth.

4. We purchase DOB and CSMs from MP pharmaceuticals since it reduces labor and variability between media batches (see http://www.mpbio.com/ for a more detailed formulation of CSMs). Other brands are possible but be aware that variation in results can be obtained when using media from different suppliers. 
5. We have found that autoclaving minimal media longer times produces browning resulting in poor yeast growth.

6. This is a toxic substance and requires using personal protective equipment. 3-AT is a competitive inhibitor of the product of the HIS3 reporter gene.

7. We always use PEG 4000 from Merck since we did not have transformants when we used the equivalent product from a different supplier.

8. The optimal amount of carrier DNA is $100-200 \mu \mathrm{g}$, which increases the number of transformants about two-fold. However, when high transformation efficiency is not required, addition of carrier DNA may be omitted.

9. We do not use denatured alcohol to flame the replicator since it usually contains quaternary amines that inhibit yeast growth.

10. This methodology has been used to screen an Arabidopsis library of TFs (ca. 1200 Arabidopsis TFs arrayed in fifteen 96-well microtiter plates; available at the Nottingham Arabidopsis Stock Centre) with DNA or protein baits [22, 37-41]. Particularly successful have been the Y1H assays by using DNA promoter sequences identified by phylogenomic analyses, since this approach appears to filter genetic redundancy $[22,38,39,42]$. Other libraries or clone collections are also compatible with this methodology.

11. Always sterilize the replicator by flaming with absolute alcohol in-between handling of different plates. We use a custom-made replicator but any other replicator will do the job. A $3 \mathrm{~mm}$ thick stainless steel plate (to protect the methacrylate when flaming) was screwed to the bottom of a rectangular methacrylate block $(1.8 \mathrm{~cm} \times 13.3 \mathrm{~cm} \times 10.1 \mathrm{~cm})$. Then, from the top and through the whole block, stainless steel screws $(6 \mathrm{~cm} \times 3.5 \mathrm{~mm})$ were screwed in a 96-well format. For easy of handling a methacrylate handle was added. This replicator spots $\sim 5-10 \mu$ droplets on agar plates.

12. To shake the 96 -well microtiter plates we routinely use the $\mathrm{HiGro}^{\mathrm{TM}}$ Shaker (Genemachines; http://www.americaninstrument.com/pdf/4850-SHAKER.pdf) that combines a small shaking orbital $(8 \mathrm{~mm})$, gas flow, and temperature controls $\left(2.8 \mathrm{rcf}\right.$ or $250 \mathrm{rpm}, 2 \mathrm{~s}$ air flow every $30 \mathrm{~s}$, and $28^{\circ} \mathrm{C}$ ). However, in our hands, standard shakers (2.8 rcf) are also amenable to be used with this protocol provided that microtiter plates are fastened properly (i.e., sticky tape).

13. We recommend cloning the DNA sequence of interest in the $X m a I$ and $X b a I$ sites of the pTUYlH plasmid since it will remove most of the multicloning site sequences, which reduces background and distance from the HIS 3 start codon. 
14. In the case of $\mathrm{Y} 2 \mathrm{H}$, different vectors may not produce equivalent results. The pDEST22/pDEST32 vectors (Invitrogen) produce a higher fraction of interactions that are conserved and that are biologically relevant compared to the pGBKT7/ pGADT7-related vectors (Clontech; our protocol is also compatible with these plasmids), but the latter appear to be more sensitive and thus detect more interactions [43]. For these reasons, interactions observed in yeast should be confirmed in the system from where the interactors originate. In silico tools, such as tissue specific and developmental information on expression patterns, may help determine the temporal and spatial coexistence of any given pair of interactors. This information can be used to prioritize on specific interactions.

15. Four hours of incubation is enough in many cases (Dr. Benito, personal communication).

16. This titration protocol can also be used to test one-to-one (few) interactions just by including other prey constructs in addition to the controls (i.e., when confirming positive interactions). It also can be used for obtaining a more precise quantification of the strength of the interactions.

17. Plating dilutions of cultures may not be necessary since liquid cultures of diploid cells in minimal media usually reach stationary phase after 2-3 days of growth, which ensure that equivalent number of cells are being used in all cases. However, since it is possible to find differences in diploid numbers between colonies, it is advisable to plate serial dilutions of control cultures on diploid plates (DOB-L-W). For screening plates (DOB- $\mathrm{L}-\mathrm{W}-\mathrm{H} \pm 3-\mathrm{AT}$ ), spotting serial dilutions are only required for control cultures while the rest of the cultures are spotted undiluted. As an alternative option to obtain saturated cultures, especially when big differences in cell densities are observed between spotted cultures, the diploid colonies obtained can be used to inoculate fresh DOB$\mathrm{L}-\mathrm{W}$ liquid media again as in step 3 of Subheading 3.3, and continue with the protocol. This setup will allow semiquantitative comparisons of growth (interaction strength) between different yeast colonies. To determine the concentration of 3 -AT to be used in the screening plates, we initially test the following range of concentrations $(\mathrm{mM}): 0,1,5,15,30,60$, and 100 . A different range of concentrations, depending on the information you might have, based on previous work with your favorite bait, can be used. It may be necessary to repeat the titration using a tighter range of concentrations to precisely determine the lowest 3 -AT concentration that block reporter activation by your bait (after 7 days of incubation) to be used in the screening. 
18. This protocol was designed to manually screen libraries arrayed in a 96-well format and we have systematically used it with a prey library of ca. 1200 Arabidopsis thaliana TF ORFs cloned in the pDEST22 plasmid [22]. Diploid (DOB-L-W) and screening (DOB-L-W-H \pm 3 -AT) plates are inoculated with similar number of cells and grown and scored in parallel, allowing for occasional non-mating clones to be flagged as not screened. In any case, diploid colony size and density recorded after 2 days of incubation of diploid plates can be taken into account to compare and normalize the strength of positive interactions observed in screening plates. This is a very useful feature to prioritize further characterization of specific positives when too many interactors are obtained. We have observed that less diploid cells are recovered when mating Y187 with YM4271 compared to those obtained between pJ694 and YM4271. Using arrayed TF libraries instead of pooled TF collections reduces labor time since this eliminates the effort required to characterize several positives produced by the same clone. The efficiency of the protocol may be enhanced in some steps by having two people working simultaneously. Typically, we screen two baits at the same time to maximize the screening effort. Scaling up the procedure (i.e., robotization) and using other library formats (i.e., 384-wells) and yeast strains is also possible.

19. Scoring yeast growth for 7 days after plating cells will provide additional information about the strength of the interaction. Usually, the faster the growth, the stronger the interaction.

20. In some occasions, the genetic background of the yeast cells (haploid versus diploid) may affect the interaction. Although mating (diploid background) detects less interactions compared to transformation (haploid background), the first ones are more reproducible as well as better suited for highthroughput screens [15].

21. Never use liquid nitrogen to freeze cryogenic vials since most yeast cells will not survive such low temperatures. In our hands, yeast cells completely loose viability about 6 months after being stored at $4{ }^{\circ} \mathrm{C}$.

\section{Acknowledgments}

The work in L.O.-S. lab is supported by MINECO grants BIO2013-46076-R and BIO2016-77840-R. We thank to all people that contributed to the development of the Arabidopsis TF library [22] as well as all the labs that have used this resource, thus helping to ascertain its potential. We apologize to those authors whose publications are not cited here due to space limitations. 


\section{References}

1. Brent R, Ptashne M (1985) A eukaryotic transcriptional activator bearing the DNA specificity of a prokaryotic repressor. Cell 43:729-736

2. Ma J, Ptashne M (1998) Converting a eukaryotic transcriptional inhibitor into an activator. Cell 55:443-446

3. Fields S, Song O (1989) A novel genetic system to detect protein-protein interactions. Nature 340:245-246

4. Wilson TE, Fahrner TJ, Johnston M, Milbrandt $J$ (1991) Identification of the DNA binding site for NGFIB by genetic selection in yeast. Science 252:1296-1300

5. Li JJ, Herskowitz I (1993) Isolation of the ORC6, a component of the yeast origin recognition complex by a one-hybrid system. Science 262:1870-1874

6. Wang MM, Reed RR (1993) Molecular cloning of the olfactory neuronal transcription factor Olf- 1 by genetic selection in yeast. Nature 364:121-126

7. Dowell SJ, Romanowski P, Diffley JF (1994) Interaction of $\mathrm{Dbf} 4$, the $\mathrm{Cdc} 7$ protein kinase regulatory subunit, with yeast replication origins in vivo. Science 265:1243-1246

8. Inouye C, Remondelli P, Karin M, Elledge S (1994) Isolation of a cDNA encoding a metal response element binding protein using a novel expression cloning procedure: the one hybrid system. DNA Cell Biol 13:731-742

9. Rezwan M, Auerbach D (2012) Yeast "N"-hybrid systems for protein-protein and drug-protein interaction discovery. Methods $57(4): 423-429$

10. Ferro E, Trabalzini L (2013) The yeast twohybrid and related methods as powerful tools to study plant cell signalling. Plant $\mathrm{Mol} \mathrm{Biol}$ 83(4-5):287-301

11. Ji X, Wang L, Nie X, He L, Zang D, Liu Y, Zhang B, Wang Y (2014) A novel method to identify the DNA motifs recognized by a defined transcription factor. Plant $\mathrm{Mol}$ Biol $86: 367-380$

12. Ota K, Feng SY, Ito T (2014) Detecting protein-DNA interactions using a modified yeast one-hybrid system. Methods Mol Biol 1164:39-50

13. Mallick J, Jansen G, Wu C, Whiteway M (2016) SRYTH: a new yeast two-hybrid method. Methods Mol Biol 1356:31-41

14. Snider J, Stagljar I (2016) Membrane yeast two-hybrid (MYTH) mapping of full-length membrane protein interactions. Cold Spring
Harb Protoc. https://doi.org/10.1101/pdb. top077560

15. Reece-Hoyes JS, Walhout AJ (2012) Yeast one-hybrid assays: a historical and technical perspective. Methods 57(4):441-447

16. Mehla J, Caufield JH, Uetz P (2015) The yeast two-hybrid system: a tool for mapping proteinprotein interactions. Cold Spring Harb Protoc $5: 425-430$

17. Paz-Ares J (2002) REGIA, an EU project on functional genomics of transcription factors from Arabidopsis thaliana. Comp Funct Genomics 3:102-108

18. Gong W, Shen YP, Ma LG, Pan Y, Du YL, Wang DH, Yang IY, Hu LD, Liu XF, Dong $\mathrm{CX}, \mathrm{Ma} \mathrm{L}$, Chen $\mathrm{YH}$, Yang XY, Gao Y, Zhu D, Tan X, Mu JY, Zhang DB, Liu YL, DineshKumar SP, Li Y, Wang XP, Gu HY, Qu LJ, Bai SN, Lu YT, Li JY, Zhao JD, Zuo J, Huang H, Deng XW, Zhu YX (2004) Genome-wide ORFeome cloning and analysis of Arabidopsis transcription factor genes. Plant Physiol 135:773-782

19. Mitsuda N, Ikeda M, Takada S, Takiguchi Y, Kondou Y, Yoshizumi T, Fujita M, Shinozaki K, Matsui M, Ohme-Takagi M (2010) Efficient yeast one-/two-hybrid screening using a library composed only of transcription factors in Arabidopsis thaliana. Plant Cell Physiol $51: 2145-2151$

20. Arabidopsis Interactome Mapping Consortium (2011) Evidence for network evolution in an Arabidopsis interactome map. Science 333(6042):601-607

21. Brady SM, Zhang L, Megraw M, Martinez NJ, Jiang E, Yi CS, Liu W, Zeng A, Taylor-Teeples $M$, Kim D, Ahnert S, Ohler U, Ware D, Walhout AJ, Benfey PN (2011) A steleenriched gene regulatory network in the Arabidopsis root. Mol Syst Biol 7:459

22. Castrillo G, Turck F, Leveugle M, Lecharny A, Carbonero P, Coupland G, Paz-Ares J, OñateSánchez L (2011) Speeding cis-trans regulation discovery by phylogenomic analyses coupled with screenings of an arrayed library of Arabidopsis transcription factors. PLoS One $6: 21524$

23. Gaudinier A, Zhang L, Reece-Hoyes JS, Taylor-Teeples M, Pu L, Liu Z, Breton G, Pruneda-Paz JL, Kim D, Kay SA, Walhout AJ, Ware D, Brady SM (2011) Enhanced YlH assays for Arabidopsis. Nat Methods $8(12): 1053-1055$

24. Ou B, Yin KQ, Liu SN, Yang $Y$, Gu T, Wing Hui JM, Zhang L, Miao J, Kondou Y, Matsui 
M, Gu HY, Qu LJ (2011) A high-throughput screening system for Arabidopsis transcription factors and its application to Med25dependent transcriptional regulation. Mol Plant 4:546-555

25. Burdo B, Gray J, Goetting-Minesky MP, Wittler B, Hunt $M$, Li T, Velliquette $D$, Thomas J, Gentzel I, dos Santos Brito M, Mejía-Guerra MK, Connolly LN, Qaisi D, Li W, Casas MI, Doseff AI, Grotewold E (2014) The maize TFome-development of a transcription factor open reading frame collection for functional genomics. Plant J 80:356-366

26. Pruneda-Paz JL, Breton G, Nagel DH, Kang SE, Bonaldi K, Doherty CJ, Ravelo S, Galli M, Ecker JR, Kay SA (2014) A genome-scale resource for the functional characterization of Arabidopsis transcription factors. Cell Rep $8: 622-632$

27. Taylor-Teeples M, Lin L, de Lucas M, Turco G, Toal TW, Gaudinier A, Young NF, Trabucco GM, Veling MT, Lamothe R, Handakumbura PP, Xiong G, Wang C, Corwin J, Tsoukalas A, Zhang L, Ware D, Pauly M, Kliebenstein DJ, Dehesh K, Tagkopoulos I, Breton G, PrunedaPaz JL, Ahnert SE, Kay SA, Hazen SP, Brady SM (2015) An Arabidopsis gene regulatory network for secondary cell wall synthesis. Nature 517(7536):571-575

28. Liu J, Wilson TE, Milbrandt J, Johnston M (1993) Identifying DNA-binding sites and analyzing DNA-binding domains using a yeast selection system. Methods 5:125-137

29. Harper JW, Adami GR, Wei N, Keyomarsi K, Elledge SJ (1993) The p2l Cdk-interacting protein Cipl is a potent inhibitor of Gl cyclindependent kinases. Cell 75:805-816

30. James P, Halladay J, Craig EA (1996) Genomic libraries and a host strain designed for highly efficient two-hybrid selection in yeast. Genetics $144: 1425-1436$

31. Elble R (1992) A simple and efficient procedure for transformation of yeasts. Biotechniques 13(1):18-20

32. Dobi KC, Winston F (2007) Analysis of transcriptional activation at a distance in Saccharomyces cerevisiae. Mol Cell Biol 27(15):5575-5586

33. Aronheim A, Zandi E, Hennemann $H$, Elledge SJ, Karin M (1997) Isolation of an AP-1 repressor by a novel method for detecting protein-protein interactions. Mol Cell Biol 17:3094-3102

34. Stagljar I, Korostensky C, Johnsson N, te Heesen S (1998) A genetic system based on split-ubiquitin for the analysis of interactions between membrane proteins in vivo. Proc Natl Acad Sci U S A 95:5187-5192

35. Smirnov MN, Smirnov VN, Budowsky EI, Inge-Vechtomov SG, Serebrjakov NG (1967) Red pigment of adenine-deficient yeast Saccharomyces cerevisiae. Biochem Biophys Res Commun 27(3):299-304

36. Weisman LS, Bacallao R, Wickner W (1987) Multiple methods of visualizing the yeast vacuole permit evaluation of its morphology and inheritance during the cell cycle. J Cell Biol 105(4):1539-1547

37. Rueda-Romero P, Barrero-Sicilia C, GómezCadenas A, Carbonero P, Oñate-Sánchez L (2012) Arabidopsis thaliana DOF6 negatively affects germination in non-after-ripened seeds and interacts with TCP14. J Exp Bot 63:1937-1949

38. Iglesias-Fernández R, Barrero-Sicilia C, Carrillo-Barral N, Oñate-Sánchez L, Carbonero P (2013) Arabidopsis thaliana bZIP44: a transcription factor affecting seed germination and expression of the mannanase encoding gene AtMAN7. Plant J 74:767-780

39. Iglesias-Fernández R, Wozny D, Iriondo-de Hond $M$, Oñate-Sánchez L, Carbonero $\mathrm{P}$, Barrero-Sicilia C (2014) The AtCathB3 gene, encoding a cathepsin B-like protease, is expressed during germination of Arabidopsis thaliana and transcriptionally repressed by the basic leucine zipperP protein GBF1. J Exp Bot 65:2009-2021

40. Marín-de la Rosa N, Sotillo B, Mizckolczi P, Gibbs DJ, Vicente J, Carbonero P, OñateSánchez L, Holdsworth MJ, Bhalerao R, Alabadí D, Blázquez MA (2014) Large-scale identification of gibberellin-related transcription factors defines Group VII ERFs as functional DELLA partners. Plant Physiol 166:1022-1032

41. Ballester P, Navarrete-Gomez M, Carbonero P, Oñate-Sánchez L, Ferrándiz C (2015) Leaf expansion in Arabidopsis is controlled by a TCP-NGA regulatory module likely conserved in distantly related species. Physiol Plant $155: 21-32$

42. Rombolá-Caldentey B, Rueda-Romero P, Iglesias-Fernández $\mathrm{R}$, Carbonero $\mathrm{P}$, OñateSánchez L (2014) Arabidopsis DELLA and two HD-ZIP transcription factors regulate GA signalling in the epidermis through the Ll-box cis-element. Plant Cell 26:2905-2919

43. Rajagopala SV, Hughes KT, Uetz P (2009) Benchmarking yeast two-hybrid systems using the interactions of bacterial motility proteins. Proteomics 9:5296-5302 